\title{
Cartografia dos Estágios em Arte no Ensino Remoto
}

A Cartography of Internships in Arts through Remote Teaching

\author{
Juliana Maria Girão Carvalho Nascimento
}

Resumo: Este artigo traz uma cartografia dos Estágios Supervisionados I e II da Licenciatura em Teatro da UFC, desenvolvidos no contexto da pandemia de COVID-19 (entre 08/2020 e 04/2021), com o intuito de mostrar os disparadores criados nas disciplinas para mobilizar as(os) estagiárias(os) em suas práticas e pesquisas docentes, junto à disciplina de Arte no ensino fundamental II. Os territórios virtuais de três escolas públicas são delineados a partir da habitação de professoras(es) de Arte, orientadora de estágio e estagiárias(os). Por fim, o artigo mostra como os disparadores propostos pela orientação reverberaram nas práticas pedagógicas das(os) estagiários, na sala virtual de Arte, a partir de metodologias que articulam a BNCC, a inventividade, a aplicação da Lei $n^{\circ} 11.645$ e o pensamento decolonial, em prol da criação de uma pedagogia do contra-isolamento.

Palavras-chave: Ensino de Arte; Ensino remoto; Estágio supervisionado; Decolonialidade; Lei $n^{\circ}$ 11.645; Pedagogia do contra-isolamento.

Abstract: This is a cartographic study of Supervised Internships I e II in Theatre undergraduate course from UFC, developed in COVID-19 pandemic background, since August 2020 until April 2021, to present the triggers developed during Art subjects in middle school. The virtual territories from three public schools are drafted from the school Art teachers', the internship supervisor's, and the interns' home. In conclusion, this study shows how the triggers supervisors have proposed reflect on interns' pedagogical practices, during the virtual Art classes, adopting methodologies that articulate BNCC, inventiveness, Law number 11.645 and decolonial paradigm, on behalf of a counter-isolation pedagogy.

Key-words: Art Education. Remote Teaching; Supervised Internship; Decoloniality. Law nr 11.645; Counter-Isolation Pedagogy.

\section{Introdução}

No dia 17 de março de 2020, foi decretado o início de um longo período de isolamento social no estado do Ceará e no Brasil. O Ensino Superior e a Educação Básica (nos âmbitos público e privado) tiveram suas aulas presenciais suspensas. Suspensão é uma palavra significativa nesse contexto: nós, professoras(es) e alunas(os), ficamos suspensas(os), em vários sentidos que essa palavra pode trazer - interrompidas(os), hesitantes, perplexas(os), sustadas(os), paradas(os), atônitas(os). Acreditando que em alguns meses retornaríamos ao encontro presencial, sem querer comprometer a qualidade das inúmeras disciplinas e atividades práticas presenciais que um curso de 
teatro demanda, e investindo no diálogo com as(os) discentes para compreender suas realidades de vida e encontrar modos mais inclusivos de retomar as aulas, demoramos mais do que a Educação Básica a responder às urgências que a pandemia nos colocou. Quando o colegiado do Curso de Teatro da Universidade Federal do Ceará (UFC) elaborou o seu plano pedagógico emergencial, era julho de 2020 e a Educação Básica já havia passado por várias fases em suas tentativas pedagógicas de manter os vínculos com as(os) alunas(os).

É importante destacar que, como não houve uma orientação unificada por parte das Secretarias Municipais e Estaduais de Educação, cada escola buscou suas estratégias a partir da realidade do seu público, em tentativas que foram se modificando rapidamente. Ainda não havia dados sistematizados, tampouco pesquisas disponíveis sobre as formas de ensino remoto adotadas, então os dados que aqui serão apresentados foram produzidos a partir da escuta das(os) professoras(es) de arte de cada escola envolvida nos estágios e do levantamento de matérias de jornais e blogs sobre o tema ${ }^{1}$. Era preciso compreender que escolas eram essas, que deixaram de existir enquanto espaços físicos tonando-se territórios virtuais.

Tanto a Etnografia quanto a Cartografia, ambas referenciais teóricometodológicos de pesquisa que costumo abordar nos estágios, pressupõem um deslocamento espacial e um estar no campo com o outro, ou seja, o convívio com o outro em seu locus. Para a Cartografia, é fundamental a ideia de habitar um território que, por sua vez, não se confunde com um meio ambiente a ser retratado, devido à "espessura processual" que carrega, com suas pulsações, ritmos, cheiros, corpos etc. (KASTRUP, 2009). Laura Barros e Virgínia Kastrup $(2009$, p.56) afirmam que "A pesquisa de campo requer a habitação de um território que, em princípio, ele [o cartógrafo] não habita. Nesta medida, a cartografia se aproxima da pesquisa etnográfica e lança mão da observação participante." As autoras apontam vários elementos de

\footnotetext{
1 Atualmente, já existem pesquisas sistematizadas com dados estatísticos sobre os formatos de ensino remoto adotado no Brasil, como a pesquisa intitulada "Retratos da Educação no Contexto da Pandemia do Coronavírus - um olhar sobre múltiplas desigualdades", organizada pela Fundação Carlos Chagas. Porém, opto aqui por trazer os dados produzidos a partir das singularidades dos territórios habitados.
} 
aproximação entre essas dois referenciais, um dos motivos que me leva a apresentar os dois para as(os) estagiárias(os), para que eles compreendam a ideia de observação participante.

O trabalho com esses referenciais é um dos primeiros passos proposto nos estágios que procurei manter no trânsito do formato presencial para o remoto, pois percebi que a ideia que as(os) discentes tinham da observação (proposta sobretudo no Estágio $\left.\right|^{2}$ ) partia de uma relação de separação entre sujeito e objeto de pesquisa, na qual o sujeito pesquisador deveria guardar uma posição de neutralidade e distância em relação ao "objeto" e ao campo investigado, de modo a não interferir nas interações sociais e produções simbólicas dos sujeitos do campo.

Essa posição aparentemente neutra e silenciosa da(o) estagiária(o), que olhava e escrevia sem interagir, chegava muitas vezes para professoras(es) e alunas(os) das escolas como vigilância e julgamento. Eram comuns frases como: "tio, tá escrevendo o que aí?"; "o tio tá aqui de olho em tudo, só anotando". Ou o professor pedir para os alunos se comportarem, senão o "tio estagiário" iria anotar quem estava se comportando mal e falar para a diretora; até o incômodo por parte do professor de ter alguém ali só observando sem colaborar com o andamento da aula. Em minha escuta na sala de aula da disciplina de Estágio I, esse olhar silencioso de muitas(os) estagiárias(os) se traduzia em julgamento explícito sobre a forma de conduzir as aulas por parte $\mathrm{da}(\mathrm{o})$ professora(o) supervisora(o), que em alguns casos não era considerada adequada pelas(os) estagiárias(os) para o ensino de arte, o que me levou a perceber que elas(es) se identificavam muito mais com o lugar do aluno do que com o do docente. Desde 2017, foram inúmeras as vezes em que ouvi as(os) estagiárias(os) verbalizarem sobre a dificuldade de encontrar o seu lugar na escola, pois eram tratadas(os) pelas(os) alunas(os) como professoras(es), mas não se viam como tal, como se estivessem num entrelugar entre aluno e professor $^{3}$. Nesse sentido, tanto a Etnografia (e a observação participante)

2 No currículo do curso, o Estágio I propõe observação com intervenções pontuais na disciplina de Arte no Ensino Fundamental II, e o Estágio II a regência nesse mesmo nível de ensino.

3 Se trago aqui alguns elementos dos estágios presenciais, é por compreender que, para cartografar os processos de estágio remoto, é preciso destacar questões e desafios que permanecem nesse trânsito do presencial para o virtual e o que emerge de novo - inclusive 
quanto a Cartografia vieram como um modo de provocar nas(os) estagiárias(os) um estar no campo diverso da observação neutra e distante, e também de instigar outras formas de pesquisar, estimulando ainda uma narratividade na escrita que pressupõe trazer os corpos, as cenas e as vozes dos diversos sujeitos envolvidos. Ademais, tentei mobilizar nas(os) estagiárias(os) um sentimento de pertença a essa classe de trabalhadoras(es), de aprendizagem e de colaboração mútuas.

Barros e Kastrup (2009) afirmam que a pesquisa de campo pressupõe habitar um território antes desconhecido. Cada escola, enquanto microcampo, vai ter suas singularidades, mas vai também preservar algo em comum ao conceito de escola. Por outro lado, todas(os) passamos grande parte de nossas vidas em uma ou várias escolas, de modo que, quando retornamos a esse lugar (como docente ou estagiária/o), levamos conosco uma ideia préconcebida de escola, de professor e de aluno, a partir de nossas experiências pessoais. Nesse sentido, faz-se fundamental a aposta de base etnográfica "[...] de não apenas familiarizar o distante, como também de estranhar o próximo" (OLIVEIRA, 2013, p.272). Barros e Kastrup (2009) tomam emprestada essa premissa etnográfica para pensar o modo de habitar o território e cartografar processos em curso, sublinhando que essa atitude de estranhamento precisa ser construída e requer abertura ao novo e ao inesperado. Como orientadora, faço um paralelo com o conceito de estranhamento de Brecht, para ajudar as(os) estagiárias(os) a compreender o estranhamento etnográfico, no intuito de levá-las(os) não só a se descolarem de sua visão pré-concebida de escola, como também a desnaturalizar as práticas escolares, percebendo-as como construídas socialmente e passíveis de transformação.

Mas afinal como cartografar ou etnografar um território virtual, onde os corpos, quando se deixam ver (o que tem sido raro), estão mediados pela tela do celular ou computador, além de recortados e restritos ao peito/cabeça e mãos?

porque muitas proposições para os estágios na pandemia, como o pensamento decolonial e o ensino antirracista, vêm como respostas a questões anteriores, mobilizadas pelas(os) discentes. Aqui, assumo, ainda, um modo de agenciar a experiência pelo relato que opera numa bricolagem entre a Etnografia e a Cartografia, nesse lugar de instigadora da formação docente em arte. 


\section{Contextos da escola virtual: criação e habitação de novos territórios}

Acerca do ensino remoto numa escola municipal de Fortaleza, nos contextualiza o professor Getsêmane Machado (Get):

Assim, o instrumento normativo [da SME] é, a deliberação que existia é: a gente precisa enviar planos e atividades semanais. Pronto. Mas enfim, se organizaram esses grupos [de WhatsApp], grupos fechados, com horários [...], que você entrava lá no grupo e mobilizava como ia funcionar a sua aula. Então tinha professor que só mandava áudio e texto pelo WhatsApp; eu não quis fazer isso. [...]. Eu criei um sitezinho, um Google site, onde lá tem todo o repositório de conteúdo da minha disciplina, e promovi conferências pelo Google Meet. Isso [das conferências] já foi bem recente, tá? Já tipo um mês antes da gente entrar de férias... E aí por que? Porque assim, é uma coisa sem fim, né... Quando abre o grupo, tipo assim, entrei no meu horário e aí abre pros alunos entrarem também, poderem escrever, aí é uma loucura, você manda áudio, não entendem, manda texto, aquela coisa. Não, vou logo para o Google Meet, falo, já que estão me exigindo isso, estar nesse lugar [do ensino remoto], vou trabalhar dessa forma. E assim foi. [...] Não tem um negócio muito fechado, entende? (Depoimento enviado por áudio de WhatsApp pelo professor de Arte das escolas municipais João Estanislau Façanha e Moura Brasil, no dia 21 de agosto de 2020).

O depoimento acima retrata tanto as inúmeras tentativas feitas pelas escolas, como a falta de unificação não só dentro da rede municipal, mas dentro de uma mesma escola. As turmas e salas viraram grupos de WhatsApp, em muitas escolas; na maioria desses grupos, as(os) alunas(os) não podiam enviar mensagens (somente receber), ou então só podiam enviar mensagens durante o horário específico da aula - o que interpreto como a realização de um desejo de silenciamento do alunado, mas que também ser lido por um viés operacional, de evitar que se dispersem as mensagens de orientação das atividades.

Get, formado em Publicidade e licenciado egresso do Curso de Teatro da UFC, ex-preceptor do primeiro núcleo de arte do Programa de Residência Pedagógica, é professor efetivo de Arte da Rede Pública Municipal de Fortaleza, atuando nas escolas João Estanislau Façanha (no bairro Maraponga) e Moura Brasil (no Pirambu). A sua formação em Publicidade, a sua criatividade e a sua habilidade com as tecnologias de informação e 
comunicação fazem com que ele seja uma exceção, comparado aos demais professores, na relação com o ensino remoto. O site foi uma plataforma muito importante para ele e para as(os) alunas(os), como indica o depoimento a seguir:

Amada, se não fosse esse site! Porque o que era que acontecia antes, né? O professor mandava lá PDF, mandava imagem, uma hora o menino dizia assim: "meu celular bugou, perdi tudo". Ou colocava assim, "meu celular tá pesado, não consigo baixar mais nada". Aí eu [pensei], cara, vou fazer um site que aí é o link que ele entra, não precisa baixar nada, coloco os conteúdos extra lá e aí morreu! (Áudio de WhatsApp enviado por Get, professor de Arte da escola João Estanislau Façanha, no dia 21 de agosto de 2020).

Get pontuou que o site ajudou a incluir e situar os alunos que retornaram às aulas dois ou três meses depois do início da pandemia. Convém situar que esses áudios foram solicitados por mim (orientadora) às(aos) professoras(es) supervisoras(es) parceiras(os), antes do início das aulas, para que eu pudesse compreender o formato adotado por cada escola, bem como contextualizar as(os) estagiárias(os) no início da disciplina - inclusive as(os) professoras(es) permitiram que eu enviasse os áudios para a minha turma, também organizada num grupo de WhatsApp e com aulas síncronas pelo Google Meet.

No modo presencial, as(os) estagiárias(os) eram livres para escolher a escola em que quisessem atuar. Essa escolha envolvia questões de deslocamento (muitos optavam por estagiar no seu bairro ou perto da UFC) e de afetos (outros queriam estagiar onde haviam estudado). Porém, eu sempre enviava uma lista de indicações de escolas com professoras(es) de arte formadas(os) em uma linguagem artística. Já no estágio remoto, optamos por trabalhar com escolas e professoras(es) específicos, distribuindo as(os) estagiárias(os) entre três escolas: Escola João Estanislau Façanha, Escola Nossa Senhora do Perpétuo Socorro (que no estágio II foi substituída pela Escola José Macambira), e Colégio da Polícia Militar General Edgar Facó (CPM).

É importante destacar que retomar os estágios no ensino remoto foi uma escolha política, pois o colegiado optou por adiar várias disciplinas práticas, mas defendeu a importância de estar ao lado das(os) professoras(es) da 
Educação Básica nesse momento, numa tentativa de somar forças na busca de plataformas acessíveis e estratégias pedagógicas mobilizadoras das(os) alunas(os). Estar nas escolas em equipes de trabalhos gerou em nós um senso de comunidade, de troca e de colaboração muito valiosos para o processo.

Seguindo na contextualização desse território escolar virtual e múltiplo, o Colégio da Polícia Militar (CPM) também passou por várias fases na implantação do ensino remoto, porém de um modo mais unificado, organizado e imposto pelo corpo gestor (que é composto por oficiais de alta patente da Polícia Militar), sem que as(os) professores tivessem escolha. A primeira orientação foi de que cada professor/a criasse salas de aula no Google Classroom em seus gmails pessoais, uma sala para cada turma. Débora Frota abriu 26 turmas/salas no Classroom, para postar atividades e videoaulas, a cada semana, seguindo um horário fixo. As disciplinas de "Linguagens e códigos" tinham que "[...] postar toda terça feira um conteúdo, que era o conteúdo do livro, e uma atividade para o estudante fazer em casa, e essa atividade a posteriori ia ser a nota da primeira etapa, porque ainda não tinha fechado o primeiro bimestre" (trecho de áudio de WhatsApp da professora de arte do CPM, Débora Frota, enviado 21 em agosto de 2021). Esse formato foi até maio, quando os pais começaram a questionar, junto à gestão, as estratégias adotadas, como: as videoaulas postadas pelos professores, que eram retiradas do YouTube de terceiros (o que, segundo os pais, causava um estranhamento em termos de didática e metodologia, por parte das/os alunas/os); as postagens de atividades (para os pais, não estava funcionando esse sistema de ler o livro e fazer atividade); poucos professores tinham contato pelo Google Meet e as(os) alunas(os) estavam com saudades.

Em junho, a gestão do CPM encaminhou aos professores outra "orientação", a ser implantada a partir de agosto. As(os) professoras(es) teriam que gravar e publicar o que Débora chama de "videoaulas autorais" - elas(es) até poderiam postar vídeos de terceiros, mas como material complementar. Assim, em 2020.2, quando as(os) estagiárias(os) entraram nas escolas, o que estava consolidado no CPM era uma alternância entre aula síncrona no Google Meet, juntando várias turmas de uma mesma série e turno, e aulas 
assíncronas, através das videoaulas autorais. Ademais, no retorno às aulas em agosto, a Secretaria de Educação do Estado do Ceará tinha criado um e-mail institucional para professoras(es) e alunas(os) da rede estadual, de modo que as(os) docentes do CPM tiveram que fechar seu Classroom pessoal e migrar para a sala institucional da SEDUC. As aulas síncronas passaram de 45 minutos para 40 e as videoaulas deveriam ter entre 15 e 20 minutos. Em um de seus áudios, a professora fez sua própria avaliação:

Pensando nesse histórico todo, eu penso que o Colégio da
Polícia seguiu muito parecido com o calendário, o cronograma
e a organização das escolas particulares, com uma
organização bem centrada, muito rapidamente solucionada e
imposta, né, claro, aos professores. (Trecho de áudio de
WhatsApp da professora de arte do CPM, enviado 21 em
agosto de 2021).

Nessa lógica similar à da escola particular, a gestão impôs ainda aos alunos que assistissem às aulas fardados e com as câmeras ligadas, seguindo com o pensamento disciplinador próprio das escolas militares, numa tentativa talvez de transpor o presencial para o remoto, o que gerou bastante desconforto e reclamações por parte dos pais, já que as aulas invadem o ambiente familiar. Débora relatou ainda que a partir dessas diretrizes, houve vários problemas com as(os) professoras(es), pois muitas(os) adoeceram, tiraram licença, tiveram familiares doentes, além das(os) que não se adaptaram ao Classroom. Já no primeiro semestre de 2021 , as videoaulas foram retiradas e todas as aulas passaram a ser síncronas, ainda pelo Google Meet.

Para as(os) alunas(os) com dificuldades de acesso à internet, o CPM propôs duas alternativas: o laboratório de informática da escola foi disponibilizado diariamente para uma parte delas(es), que vão assistir à aula lá; e as(os) professoras(es) disponibilizam um plano de estudo com atividades semanais assíncronas (impressas pela gestão) para as(os) que não podem ir à escola, nem acessar às aulas ao vivo. Aliás, esse envio de plano de estudos com atividades impressas, para quem não tem condições de assistir às aulas síncronas, tem sido uma estratégia comum a todas as escolas as quais habitamos nesse processo, modificando-se somente a sistemática de tempo (entre semanal e quinzenal). 
Na Escola Professor José Rebouças Macambira, na qual ingressamos no início de fevereiro de 2021, com o Estágio II, as aulas estavam sendo síncronas através do aplicativo Zoom, com duração entre 20 e 30 minutos - o aplicativo encerrava a aula automaticamente quando chegava nos 30 minutos, o que causava uma correria no final das aulas, para fazer a frequência (via Google formulário) e finalizar. Arnoldo, professor temporário da Rede Municipal, também é licenciado em Teatro pela UFC. Em nossas conversas, ele me situou que a maior dificuldade dele era provocar a participação das(os) alunas(os) nas aulas, pois muitas(os) entravam na sala e ficavam caladas(os) e com as câmeras desligadas até o momento da frequência. Assim como no CPM, e posteriormente no Estanislau, o professor priorizava o trabalho com o livro didático, considerado pelas(os) professoras(es) de arte uma conquista política que deve ser valorizada, mas também pelo fato de ser o material acessível a todas(os) as(os) estudantes. O supervisor permitiu que as(os) estagiárias(os) escolhessem os capítulos com os quais iriam trabalhar, o que também ocorreu nas demais escolas parceiras. Ele orientou ainda que as(os) estagiários utilizassem slides e evitassem ligar as suas câmeras, para não dispersar as(os) alunas(os). Apesar de, em algumas situações, os slides (aliado ao curto tempo de aula) implicarem numa aula expositiva e monológica, eles ajudaram na organização do pensamento das(os) estagiárias(os), que encontraram ferramentas interessantes e interativas, como a inclusão de imagens e de vídeos dentro deles.

No entanto, muitas(os) delas(es) romperam com o acordo da câmera desligada, a partir de propostas de jogar artisticamente com as(os) alunas(os) e com o tema da aula com o intuito de mobilizar a participação. Foi o caso de Fernando Otto e Vitória Vaz, que ao trabalharem o tema Circo, realizaram intervenções nas aulas com seus palhaços (o Palhaço Palhaço e a Pimpolha), saindo da performance docente e cativando as(os) alunos com tiradas irreverentes e divertidas, que dificilmente um professor falaria. Para Fernando, essa intervenção jogava com seu recorte de pesquisa, que era mobilizar a relação ensino/aprendizagem através do humor. 
Para concluir essa etapa de contextualização, é importante frisar que as(os) professoras(es) supervisoras(es) acompanhavam as aulas das(os) suas/seus estagiárias(os), bem como comentavam essas aulas, dando dicas pedagógicas e retornos sobre as fortalezas e fragilidades delas. Enquanto orientadora, observei e comentei, no mínimo, uma aula síncrona regida por cada estagiária(o) - assisti também às videoaulas feitas por elas(es), ainda que se somassem às aulas síncronas. Meus comentários se constituíram numa perspectiva de avaliação formativa, sempre começando por destacar as potências e fortalezas das aulas e da postura docente das(os) estagiárias(os), bem como indicando pontos que poderiam ser mais desenvolvidos e até momentos em que o plano poderia ter sido abandonado em prol de um debate importante - como foi o caso em que uma aluna da Estanislau Façanha trouxe depoimentos de racismo que ela sofreu, no debate de uma fotografia que mostrava três homens negros com a palavra "poder" pintada de branco em seus tórax. Nesta aula, que tinha como tema "o corpo fala", a estagiária acolheu e comentou o depoimento da aluna, porém de modo pontual, seguindo com o plano de aula. Depois, comentei que naquele momento ela tinha material e demanda para ampliar o debate sobre racismo com a turma, mesmo que isso implicasse em mudar o curso do planejamento. Até porque o recorte de pesquisa de Larissa Gondim e sua dupla partia da questão: "Como desenvolver um ensino decolonial a partir dos livros de Artes usados na escola?" (Trecho do plano de estágio de Larissa Gondim e Carolina Feitosa, p.03, 26/02/2021).

Como é possível perceber nesses relatos, na pandemia, o meu papel enquanto mediadora entre professoras(es) supervisoras(es) e estagiárias(os) se aprofundou. Ademais, a percepção do adoecimento que tem atravessado a experiência docente nesses tempos, fez-me redobrar os cuidados em relação a essas(es) colegas, no sentido de explicitar para as(os) estagiárias(os) que nós estamos entrando no território delas(es), portanto precisamos respeitar os limites e rotinas propostos.

\section{Disparadores para o estágio remoto em Arte}


Pensar o estágio enquanto pesquisa é um dos princípios que venho cultivando. A ideia é que, a partir de uma atitude de abertura e receptividade ao território e de uma observação participante, cada estagiária(o) desenvolva uma questão de pesquisa sobre a docência em arte, questão que pode estar aliada às proposições de regência de cada um(a), configurando-se enquanto uma pesquisa interventiva.

O que o ensino de arte pode fazer em tempos de pandemia? Do que estamos necessitando nesse momento? Desde o início, ficou nítido que o que quer que fôssemos investigar, aprender e experimentar nos estágios precisava considerar a pandemia e as mudanças que ela provocou em nossas vidas.

Assim, em nossa primeira aula no formato remoto, eu já havia compartilhado no grupo de WhatsApp os áudios das(os) professoras(es) supervisoras(es), contextualizando suas escolas, bem como os links dos sites/blogs e perfil de Instagram criados por elas(es). A aula partiu do debate desses materiais e de algumas questões, no intuito de disparar o pensamento sobre pesquisa e formação docente: em quais pontos as experiências dos três professores se aproximam e se distanciam? O que os materiais que eu enviei representam para nós na disciplina? O que queremos saber/descobrir nessa experiência de estágio no ensino remoto? Como pesquisar num território virtual?

As(os) estagiárias(os) pontuaram que o acesso dos alunos à internet é irregular e que o contexto pandêmico só vem escancarar a precarização do Ensino Público. Observaram que a escola tenta padronizar os alunos, como se não houvesse particularidades entre eles, e que a entrada da escola nos lares torna essa padronização ainda mais violenta. Atentaram também para o fato de que as(os) professoras(es) estão descobrindo esses novos ambientes virtuais e, nessa descoberta, deparam-se com tarefas para as quais não estão preparadas(os) (como gravar e editar vídeos) ${ }^{4}$. Ficou nítido para as(os) discentes que os áudios de WhatsApp e links enviados eram materiais e

4 Em debate no Estágio II, levei matérias e artigos diferenciando o ensino remoto do ensino à distância, para que as(os) estagiários compreendessem que funções como filmar e editar videoaulas, bem como organizar a plataforma Classroom, são exercidas por profissionais distintos no EAD, representando assim um acúmulo de trabalho para as(os) professoras(es) que se encontram no ensino remoto atualmente. 
estratégias de pesquisa, além de um registro dos procedimentos de trabalho criados nessas escolas. Assim, demarcamos que a pesquisa e observação participante desses territórios precisava se debruçar sobre esses materiais virtuais assíncronos; já nas aulas síncronas, pontuamos a importância de observar e interagir no chat de mensagens (do Meet e do Zoom), que configura-se como um espaço de fala para alunas(os) que não podem ou não querem abrir o microfone - é interessante perceber que alguns professores comparam o chat à "conversa paralela", visto que algumas mensagens desviam-se do assunto da aula.

A orientação que dou é de que as(os) estagiárias(os) não fechem seu recorte de pesquisa antes de habitar esse território por um período mínimo, porque, às vezes, o campo mostra uma questão que é mais pulsante para ele do que a que a(o) estagiária(o) havia proposto.

Assim uma tempestade de ideias aconteceu acerca do que queríamos descobrir: Que estratégias pedagógicas os professores estão utilizando para mobilizar o sensível, a performatividade e a criação artística no ensino remoto de arte? Como a pandemia e o isolamento estão provocando uma hibridização das linguagens artísticas no ensino de arte? Como acionar a atenção, a participação e a subjetividade das(os) alunas(os)? Em que medida as(os) professoras(es) estão acionando a experiência do isolamento e da pandemia em suas propostas criativas para as aulas de arte? Como estão sendo compostas as estratégias de avaliação, de modo a possibilitar o acesso de todas(os)?

Nessas questões, já é perceptível o que era importante para as(os) estagiárias(os) no ensino de arte, expondo em suas inquietações as dimensões do encontro e da experiência, tão caras ao teatro. O encontro também é caro à Educação, como nos lembra o educador argentino Mariano Narodowski (2020, p.01), no artigo Onze teses urgentes para uma pedagogia do contraisolamento, que foi um dos nossos disparadores iniciais nesse processo:

A pedagogia [...] é o oposto do isolamento. Suas ferramentas são baseadas no encontro entre educadores e alunos em um ambiente escolar que transforma esse vínculo em um fato único e intransferível. Um encontro articulado em torno do 
conhecimento. Uma profunda experiência no intelectual, no emocional e no corpo. Um compartilhamento que, embora às vezes deixe traços lamentáveis e hostis, aparece como uma singularidade insubstituível.

O artigo aponta ainda que $\mathrm{O}$ isolamento social aprofunda as desigualdades anteriormente existentes no acesso à educação, bem como nos lembra que "a casa é o oposto da escola", por ser um ambiente íntimo e privado em que familiares não estavam preparados para assumir algumas funções pedagógicas das escolas. Nesse sentido, Narodowski (2020, p.01), além de problematizar as consequências do isolamento social para a educação formal, aponta algumas pistas para construir o que ele chama de pedagogia do contra-isolamento: "O que podemos fazer é começar adaptando nossas expectativas à nova realidade, permitindo-nos uma maior flexibilidade, selecionando inteligentemente conteúdo, atividades, cuidados, quantidades e qualidades." Ao empuxo a um fazer hiperprodutivo para manter a engrenagem educacional funcionando, o autor contrapõe que

Priorizar conteúdo e experiências parece menos ambicioso, mas mais realista do que dar continuidade ao que não existe mais. Priorizar significa construir critérios de relevância entre disciplinas, conteúdo e conhecimento, mas também em relação ao vínculo com e entre os alunos. [...] Talvez o primeiro critério de priorização seja a situação socioemocional de nossos alunos e de nós mesmos: o vínculo e o contexto socioeconômico processados no confinamento não podem ser ignorados $[\ldots]$.

Priorizar é o começo da pedagogia do contra-isolamento. É estabelecer sentidos profundos que nos unem através do conhecimento e encontro que, embora remotos e mediados, nos permitem reconstruir a relação pedagógica que perdemos. (NARODOWSKI, 2020, p.01).

Então, o que priorizar na preparação das(os) estagiárias(os) e no ensino remoto de arte nas escolas? Nas redes sociais, nos jornais, muito se falava sobre o quanto as produções artísticas e audiovisuais (lives, peças online, filmes, séries etc.) estavam ajudando as pessoas a suportarem o isolamento social. A Psicanálise, desde Freud, já indicava que a Arte sempre se configurou como canal de expressão privilegiada das formações do inconsciente, mostrando que a fantasia funciona como uma espécie de tela protetora que 
mediatiza o encontro dos seres humanos com o real do horror e da morte. Então, por que não priorizar, nas aulas de arte, estratégias (de fruição e criação) e temáticas que possibilitem aos alunos e a nós mesmas(os) escapar? Estratégias de escape para que a fantasia voe alto e longe e perto! Estratégias de escape que joguem com a elaboração da experiência do isolamento, com a autobiografia, com os objetos do cotidiano, como propôs a estagiária Tulipa Magalhães.

Narodowski (2020, p.01) finaliza o seu artigo com a décima primeira tese, escrita como uma espécie de koan (ou quem sabe uma prece para nos livrar das angústias do medo de errar): "Não há receitas para o novo. Não há poções mágicas. No contra-isolamento, há tudo o que pensar e o que fazer. Educação é a possibilidade do pensamento. O pensamento é o vírus que devemos pegar."

Ele refere-se a um pensamento que inventa, que constrói mundos possíveis, que enfrenta o desafio do novo. A esse desafio, a princípio assustador, aliou-se ao debate, nesse mesmo encontro, um artigo de Bell Hooks (2000), que veio acrescentar o corpo e a paixão ao processo:

\begin{abstract}
Além do domínio do pensamento crítico, é igualmente crucial que aprendamos a entrar na sala de aula "inteiras" e não como "espíritos descorporificados". Nos primeiros tempos das aulas de "Estudos da Mulher" [...], aprendi pelo exemplo de ousadas e corajosas professoras mulheres [...] que havia um lugar para a paixão na sala de aula, que eros e o erótico não tinham necessidade de ser negados para que a aprendizagem ocorresse. Um dos princípios centrais da pedagogia crítica feminista tem sido a insistência em não reforçar a "divisão" mente/corpo. (HOOKS, 2000, p.84).
\end{abstract}

Hooks (2000, p.87) nos provoca a pensar com esse corpo de coração inteiro, que rompe com uma concepção "[...] baseada na falsa pressuposição de que a educação é neutra, de que há alguma base emocional 'equilibrada' sobre a qual podemos nos apoiar de modo a podermos tratar todos igualmente, desapaixonadamente." Hooks reivindica o lugar do corpo que dança, que tem cor e cheiro, reivindica o lugar do amor e da paixão na sala de aula. Em diálogo com esses dois autores, nosso debate sobre o que pode o ensino de arte em tempos de pandemia partiu da pergunta disparadora: o que pode nos guiar 
para manter acesa a paixão do encontro? Mais ainda: como jogar com um corpo recortado e mediado pela câmera? Como mobilizar um corpo que se oculta sob a câmera desligada, um corpo que se diz envergonhado de si mesmo?

Antes de apontar alguns procedimentos metodológicos criados pelas(os) estagiárias(os), cabe sintetizar as prioridades que elencamos juntas(os) para compor o repertório teórico da disciplina, seguindo o conselho de Narodowski. A primeira delas foi promover uma visada geral da Base Nacional Curricular Comum - BNCC (BRASIL, 2018), compreendendo inicialmente a proposta das competências gerais - o que foi realizado de forma assíncrona, por meio da partilha de dois podcasts do canal BNCC Singularidades (do Instituto Singularidades). O documento completo da BNCC foi disponibilizado para a turma, que se dividiu em equipes de partilha para abordar as seis dimensões propostas para o ensino de arte (criação, crítica, estesia, expressão, fruição e reflexão), as linguagens artísticas abarcadas na Base, suas habilidades e competências, considerando a parte do documento voltada para o Ensino Fundamental II, além de alguns artigos de crítica ao documento.

Com a BNCC, cada equipe de trabalho deveria produzir um material assíncrono para ser compartilhado com os demais grupos, apresentando os principais pontos abordados no documento, a linha de raciocínio construída em cada linguagem, desafios para a implementação e pontos críticos. Provoquei as(os) estagiários a relacionarem as diretrizes da BNCC com os livros didáticos adotados nas escolas e com a prática docente das(os) professoras(es) supervisoras(es), no sentido de observar em que medida e de que formas o documento é posto em prática.

Algumas equipes produziram podcasts, que foram retomados no início do semestre letivo 2020.2 e compartilhados com as(os) novas(os) estagiárias(os). Houve uma equipe que fez um seminário assíncrono no grupo de WhatsApp da turma, tecendo uma associação entre as seis dimensões para o ensino de arte e a proposta triangular de Ana Mae Barbosa (que articula apreciação, contextualização e produção). Para a equipe da Escola Estanislau Façanha, a BNCC parecia algo desligado do debate do campo das artes, além 
de intangível. Porém, perceber a ligação entre as seis dimensões e a proposta triangular, tornou mais palpável a ideia de aplicação da BNCC no estágio e na docência. Essa articulação com a abordagem triangular só se tornou nítida para Larissa, Tulipa e Carolina quando o professor Get as fez atentar para a importância desse tripé no seu planejamento e no seu modo de trazer a Arte para dentro da sala de aula, articulando sempre conteúdo e experiência.

Diante do mundo de propostas da Base, que parece intangível pela sua amplitude (passando pela produção artística local, nacional e internacional), tentei tranquilizar as(os) estagiárias(os), lembrando-lhes que não é necessário que cada aula acione as seis dimensões ao mesmo tempo, e que, no planejamento, eles podem realizar escolhas, priorizando dimensões e habilidades específicas. Por outro lado, esse passeio pela história das artes, que vai do local ao internacional, foi algo que ficou da BNCC nesse grupo, e findou por se configurar como um gancho para a crítica aos livros didáticos, para o debate sobre decolonialidade no ensino e sobre a aplicação da Lei $n^{\circ}$ $11.645^{5}$, de 10 de março de 2008.

Apesar de serem uma conquista política e um passo importante na valorização da disciplina de arte, as coleções e livros disponíveis na rede pública - Por toda a parte (UTUARI et al, 2018), Se liga na Arte (COUTINHO et al, 2018) e Projeto Mosaico (MEIRA et al, 2015) - trazem muitas referências estéticas de obras criadas na Europa, nos Estados Unidos, no Sudeste e Sul do Brasil, com o Nordeste sendo mais representado pelos estados da Bahia e de Pernambuco. A produção artística e cultural do estado do Ceará e de sua capital, Fortaleza, é pouco representada nessas coleções, o que para estagiárias(os) e professoras(es) pode distanciar as(os) alunas(os) desse material, dando-lhes a falsa impressão de que o seu local não é produtor de arte e cultura. Num país com dimensões continentais, como o nosso, e com grande diversidade cultural, há que se fazer também uma decolonização nacional, com o intuito de promover uma visibilidade de produções culturais de

5 Esta lei torna obrigatório o ensino da história e cultura afro-brasileira e indígena no ensino fundamental e médio, nas redes públicas e privadas. A lei indica que esses conteúdos devem perpassar todo o currículo escolar, com ênfase nas disciplinas de educação artística, literatura e história brasileiras. 
locais que saiam do eixo Rio/São Paulo/Sudeste e das principais capitais. Assim, a nossa proposta (minha e das/os supervisoras/es) era de que as unidades temáticas escolhidas abrissem janelas para outras referências estéticas: referências locais, periféricas, negras e dos povos originários, que mobilizassem nas(os) alunas(os) reconhecimento identitário de seus lugares de fala, que as(os) fizessem se perceber também como seres imersos na cultura (como produtores e receptores).

Paulo Freire $(1996$, p.17) já frisava a importância do respeito e da valorização dos saberes com os quais as(os) alunas(os), principalmente das classes populares, chegam à sala de aula, "[...] saberes socialmente construídos na prática comunitária [...]". Mais ainda, destacava a necessidade de trazer para o debate as experiências de vida e a realidade concreta, promovendo um diálogo íntimo entre os saberes curriculares considerados fundamentais e a experiência social que as(os) alunas(os) têm como sujeitos.

Os debates sobre a Lei $n^{0} 11.645$ e a decolonialidade vieram se somar a esses disparadores, no sentido de promover um deslocamento epistêmico e estético no ensino de Arte, trazendo à baila modos de pensar e produzir arte não-limitados aos modelos hegemônicos. Como bem pontua Moura (2019, p.317), a proposta decolonial é inclusiva, pois

[...] trata-se de pensar co-existências: de culturas, de povos, de ciências, de artes, de pensamentos, problematizando as hierarquias (artísticas, territoriais, raciais, epistemológicas), legitimando processos anti-hegemônicos de produzir conhecimentos.

Trata-se de operar, na formação docente em Arte, em contraposição a uma espécie de cegueira que alimenta

[...] o desconhecimento das histórias, das culturas e das expressões artísticas latino-americanas como representações identitárias, mestiças, dos povos dessa região, a partir das heranças indígenas e negras, híbridas indo-americanas e afroamericanas [...]. (MOURA, 2019, p. 321).

No contexto do ensino remoto, tais debates foram abertos no Estágio II com uma fala do Babalorixá e professor da UNILAB Lincoly Jesus Pereira (2020), sobre sua pesquisa acerca da Pedagogia da Encruzilhada e do projeto 
Exú nas escolas, mostrando como é possível articular conhecimentos de matriz africana e das práticas de terreiro em diversas disciplinas da educação básica, numa perspectiva transversal e antirracista. Em seguida, disponibilizei um leque de artigos que articulam o pensamento decolonial a experiências de ensino, envolvendo teatro e educação antirracista, estágio supervisionado, educação indígena etc. Em grupos de trabalho, as(os) estagiárias(os) se organizaram a partir da escolha do material que thes interessava, compartilhando num encontro síncrono entre todas(os) a discussão levantada por cada artigo - tanto reflexões teóricas e práticas metodológicas trazidas pelo material, como fragilidades e pontos críticos. Nesse debate, fui alinhavando os princípios e conceitos que cada artigo trazia para delinear teoricamente o pensamento decolonial.

\section{Quando os princípios e disparadores ganham vida na sala de aula virtual}

Aqui, mostrarei como os disparadores e princípios propostos nos estágios se materializaram em práticas docentes na sala de aula virtual. Diante da quantidade de estagiárias(os) que acompanhei, não é possível trazer exemplos de todas(os), de modo que selecionei algumas das práticas desenvolvidas.

Começo por lasmin Dantas de Souza, jovem negra de periferia, que começou a fazer teatro no ensino médio, numa escola pública do bairro Messejana, a partir das instigações de uma dupla de estagiários do curso de Teatro da UFC - com eles e um grupo de amigas da escola, ela criou o Coletivo Cabeça, no qual atua até hoje. lasmin, filha de pai PM e mãe professora, optou por realizar os estágios I e II no CPM, o que lhe proporcionou uma certa imersão no campo. Inicialmente, fazendo dupla com outra aluna, ela partilhou o mesmo recorte de pesquisa de sua colega, que se relacionava com a noção de professor-performer, pois lhe interessava investigar como pode se dar a construção de um corpo performático no ensino remoto, um corpo que mobilize a troca de afetos na relação de ensino/aprendizagem.

Sua primeira ação de regência seria assíncrona, através de uma videoaula autoral postada no Classroom, o que fez com que ela se 
perguntasse: "Como gravar uma aula didática e divertida que fizesse os alunos gostarem de assistir e que também passasse o conteúdo da aula?" (Trecho do relatório de lasmin Dantas, 20/10/2020). Em seu relatório, lasmin se assume enquanto uma jovem que consome bastante vídeos no YouTube, assim como as(os) alunas(os) do sétimo ano - seu público. Partindo das discussões levantadas por Márcia Dal Bello e Gilberto Icle (2013), acerca do corpo do professor de teatro, lasmin se coloca o desafio de ser mais atrativa aos alunos,

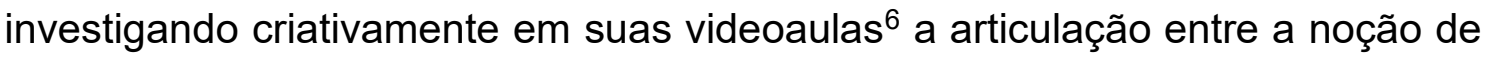
professora-performer e professora Youtuber (como ela denominou). Ela criou uma espécie de personagem Youtuber, usando uma linguagem coloquial e leve, com tiradas jocosas, gestos corporais e expressões faciais bem marcados, aproximações da câmera que geram efeito de close, mudança de planos, efeitos visuais (como figurinhas, frases e símbolos) e de edição. Ademais, inseriu trechos de vídeos de obras relacionadas ao tema das aulas ("Qual é o lugar da arte?"), como foi o caso de um trecho de BR Trans (Grupo Vertigem) - exemplo proposto pelo livro.

No trânsito entre o assíncrono e o síncrono, foi perceptível para lasmin e para a supervisora (Débora) a recepção calorosa que ela teve ao encontrar suas turmas pela primeira vez no Meet - as(os) alunas(os) a acolheram como se já a conhecesse, o que nos fez supor que ela acionou nas videoaulas um afeto e uma empatia fundamentais para sua integração no ambiente escolar virtual.

Em suas aulas síncronas, lasmin se utilizou muito do recurso da apresentação de vídeos da internet, no intuito de mostrar que a arte não está só nos museus ou outros espaços formais, articulando assim a dimensão da fruição ao apresentar práticas diversas de intervenção urbana. Houve uma aula em que ela foi do Ceará à Croácia, através de intervenções urbanas sonoras, expondo como essa linguagem artística pode mobilizar a interação das pessoas e até de um ambiente natural. Mostrou um vídeo de um grafiteiro e multiartista que eu havia Ihe indicado, Narcélio Grud, em que ele faz várias instalações sonoras no Centro de Fortaleza; em seguida, o Órgão do Mar, um

6 Para conferir uma das videoaulas de lasmin, acesse 0 link:
https://drive.google.com/file/d/1i7YstfqJu-UedXJINvaoOO1kS9oEXdle/view?usp=sharing


grande órgão construído na costa de Zadar (Croácia) e que é tocado pelo mar (na mudança das marés).

No Estágio II, apesar do CPM retirar a demanda das videoaulas, ela continuou investigando a noção de professor-performer, dessa vez pensado a partir de Naira Ciotti (2013), destacando a reflexão de que esse professor joga com seu corpo e suas experiências para mobilizar saberes e afetos. Foi com esse intuito que lasmin, numa aula síncrona sobre o mundo material e imaterial com turmas de oitavo ano, trouxe ao debate uma série da Netflix chamada Cidade Invisível, que atualiza mitos da cultura dos povos indígenas (lara, Saci, Curupira, Cuca, Boto etc.). Como diz em seu relato: "Acertei em cheio, vários alunos tinham assistido à série e ficaram bem empolgados, demandando de mim mais atenção para não perder o foco da aula" (Trecho do relatório de lasmin Dantas, 14/04/2021, p.07).

Enquanto observadora participante dessa aula, foi encantador ver a empolgação das(os) alunas(os), que trouxeram narrativas comentadas da série enquanto lasmin ia instigando e dialogando com a fala delas(es). Eu me divertia, mas num dado momento comecei a me preocupar com o tempo, receosa da aula acabar e ela não conseguir puxar o fio da meada de volta, perdendo o rumo do debate sobre ancestralidade. Foi então que lasmin, no seu slide, trouxe a fala de três indígenas (e suas fotos) fazendo críticas à série, pela falta de representatividade indígena no elenco (composto por atores e atrizes negras/os e brancas/os), e também na produção e dramaturgia, configurandose como uma série que se apropria da cultura dos povos originários de modo leviano, transformando-a mais uma vez em algo exótico para gringo ver. Nesse momento, fez-se um silêncio geral no Meet, a turma ficou muito concentrada e o pensamento do debate se transformou, inclusive com uma aluna pontuando que tinha achado estranho uma atriz negra fazer o papel da lara. No final desse debate crítico, lasmin fez ainda uma comparação entre as mitologias cristã e indígena, pontuando para a turma que, quando se aborda a história de Jesus, toma-se como uma verdade, mas quando se fala do Curupira e da lara, trata-se de folclore, expondo o quanto essa leitura parte do ponto de vista do colonizador. 
lasmin havia planejado a aula com esses dois momentos e pensado nesse ponto de virada da crítica que, além de decolonial, também articula a aplicação da Lei $n^{\circ}$ 11.645. Num áudio de WhatsApp em resposta aos meus comentários sobre a aula, ela pontuou que escolheu essa série por acreditar que ela, por ser bem produzida, poderia ser uma boa porta de entrada para a cultura indígena, desde que fossem debatidos os aspectos críticos da série - 0 que a fez acionar as dimensões da reflexão, da crítica e da fruição. Em meus comentários, destaquei a potência da linha dramatúrgica proposta, a perspicácia em mobilizar a participação e a identificação deles a partir de um material pop, e pontuei também que ela mostrou qualidades muito caras à docência, que são a escuta das(os) alunos e a sagacidade de conseguir levar a discussão de volta para os trilhos do planejado no momento preciso.

A noção de professor-performer influenciou outra estagiária, Tulipa Magalhães, que realizou seus dois estágios na Escola João Estanislau Façanha. Em conjunto com sua dupla, Francisca, que havia sido par de lasmin durante o Estágio I no CPM, Tulipa propôs "Desenvolver estratégias para a atuação em sala de aula a partir do conceito de professora-performer" (objetivo geral do plano de estágio de Tulipa e Francisca, 15/02/2021, p.03). Além disso, as duas se propuseram ainda "Articular a aplicação da Lei 10.639/03 com o conteúdo programático do livro didático a partir de uma perspectiva decolonial" (objetivo específico do plano de estágio de Tulipa e Francisca, 15/02/2021, p.03). Cabe explicitar que no Curso de Teatro da UFC é permitido que estagiárias(os) escrevam o plano em dupla, mas o relatório deve ser produzido individualmente. Aqui, vou focar em algumas proposições de Tulipa, mas destaco a importância que Francisca teve na partilha de uma ideia que acabou por mover outras duas colegas em suas experimentações docentes.

$\mathrm{Na}$ Estanislau Façanha, as estagiárias atuavam em duplas em duas séries de ensino, com uma estagiária conduzindo uma turma e a outra fazendo a assistência (projetando slides, respondendo mensagens no chat do Meet etc.) e vice-versa. Assim, Tulipa ficou responsável pela regência nas turmas de nono ano da tarde, com Francisca como assistente, e dividiu com ela as regências das turmas de sexto ano. Em uma de nossas trocas, Get comentou 
que a primeira aula síncrona da Tulipa no Estágio II foi "um caos" e ao mesmo tempo a "coisa mais linda". Em seu relatório, Tulipa também se refere à sua primeira aula como um caos, e explicita os "pensamentos e vontades" que guiaram o seu planejamento. De um modo intuitivamente autoetnográfico, ela retoma sua época de escola para pensar o que a movia e quais as expectativas que tinha com a chegada de uma nova professora:

Eu queria saber tudo sobre ela e principalmente ouvir histórias e dizer que eu vivi algo parecido, porque eu queria ter algo em comum com aquela pessoa. Ao lembrar disso, percebi que aprendia mais quando os professores chegavam com uma história, uma brincadeira, uma música do que quando chegavam mandando a gente abrir o livro. (Trecho do relatório de estágio II de Tulipa Magalhães, 30/03/2021).

Tulipa aciona suas memórias e experiências positivas como estudante para gerar uma ação que promovesse identificação entre ela e seus novos alunos. A essas memórias, ela agregou a escuta que teve no estágio anterior, quando as(os) alunas(os) queixaram-se de que no ensino remoto as(os) professoras(es) conversavam pouco e que no geral só enviavam as atividades, o que gerava dúvidas e ansiedades. Isso provocou nela o desejo de iniciar suas aulas com brincadeiras de infância, meditação guiada, músicas, histórias e mitos, além de perguntas sobre o bem-estar das(os) alunas(os), no intuito de criar vínculos que remetem ao cuidado com o outro. A partir do tema Corpo e expressão, capítulo 2 da coleção Projeto Mosaico (MEIRA et al, 2015), ela disparou sua primeira aula síncrona no Meet com a brincadeira conhecida como boca de forno, em que o mestre invoca alguns comandos e as(os) jogadoras(es) respondem em coro, até que ele indica a tarefa que devem fazer e elas(es) realizam. A brincadeira que Tulipa fez pelo Meet causou um grande alvoroço na turma do sexto ano, fazendo as(os) alunas(os) movimentarem seus corpos e jogarem. Porém,

[...] os alunos ficaram tão à vontade que ficou difícil de estabelecer um limite, e todos começaram a falar ao mesmo tempo, por isso o caos, e nesse mesmo dia teve também o episódio de um dos alunos que colocou um lençol, um óculos na cabeça e começou a dançar. (Trecho do relatório de estágio II de Tulipa Magalhães, de 30/03/2021, p.07). 
Mas foi esse caos que cativou as(os) alunas(os) e o supervisor na relação com Tulipa, além de ter promovido nela mesma um redimensionamento de sua proposta, fazendo-a perceber que era preciso criar acordos de convivência com as(os) alunas(os) sobre o respeito à fala do outro, da professora e ao andamento da aula.

A aula de Tulipa a que eu assisti, no Estágio II, era com as turmas de nono ano, em que o tema era ancestralidade e cultura (capítulo 3 do livro Projeto Mosaico). Ela iniciou sua aula falando da pangeia, contextualizou a África enquanto um continente com vários países e expôs um slide com um mapa do continente africano, mostrando também a diáspora dos povos africanos para o Brasil, seus trajetos e as etnias. Tal contextualização foi feita para introduzir a contação de um mito iorubá que narra a origem do céu (Obatalá) e da terra (Odudua), a qual Tulipa fez usando o seu corpo e ações físicas para representar algumas cenas do mito, experimentando a criação encarnada da professora-performer. Tulipa frisou ainda para sua turma que a diferença entre a mitologia africana e a grega, por exemplo, é que a africana ainda está viva nas práticas religiosas afrodescendentes.

Na segunda parte da aula, Tulipa perguntou às(aos) alunas(os) se na casa deles tem cultura, ao que responderam falando que tem samba, carnaval etc. Ela acolheu e debateu as respostas das(os) alunas(os) e em seguida trouxe uma afirmação muito precisa, que me pareceu ser o lugar central onde ela queria chegar: "Se alguém disser pra vocês que vocês não têm cultura, isso é mentira." Falou isso de um modo verdadeiro, como se dissesse também para a criança que ela foi um dia. Tulipa, uma jovem negra filha de agricultores do sertão do Ceará, finalizou a aula contando uma tradição de sua família na semana santa: seu pai todo ano fazia o boneco do Judas e juntava a comunidade para queimar, pois quem fizesse a queima do Judas estaria vingando a morte de Jesus e teria uma boa colheita naquele ano. Assim, Tulipa promoveu uma viagem cultural que partiu da África e terminou no terreiro da casa dos seus pais, para mostrar que todas(os) temos cultura, do mundo até dentro de casa, mostrando as diversas influências culturais que permeavam sua existência. 


\section{Considerações finais}

Dentre os meus achados (ou conquistas), destaco a criação das redes de colaboração e partilha que permearam todo o processo, desde a formação de duplas e equipes de trabalho, até os seminários de partilha das proposições de pesquisa e das ações pedagógicas. A intervenção pedagógica em duplas favoreceu uma observação participante mais engajada, na medida em que a função de assistência das aulas gerou uma participação ativa das(os) estagiárias(os) nas aulas conduzidas pelas(os) colegas.

Na habitação desse território virtual, fomos levadas(os) a passear e nos apropriar pedagogicamente de diversas plataformas de informação e comunicação, o que foi desafiador, mas também muito produtivo. Se por um lado a sala de aula virtual promove um distanciamento entre professor(a) e estudantes, por outro ela possibilita uma agilidade no compartilhamento de vídeos e imagens, gerando uma grande abertura para a fruição - o que no modo presencial demandaria recursos como computador e projetor (nem sempre disponíveis nas escolas), além de um tempo enorme para montar e testar os equipamentos. Porém, creio que o maior ganho foi conseguir mobilizar a dimensão pedagógica (e teatral) do encontro, com alegria, criatividade e afeto.

De minha parte, penso que a pandemia me ensinou, sobretudo, que um dos meus papéis, enquanto docente e orientadora, é diminuir a angústia das(os) estagiárias(os), mostrando-lhes que o estágio é antes de tudo um espaço de aprendizagem, de tentativas e erros, de acolhimento e de prazer, mas também um território político de habitação e resistência.

\section{Referências}

BARROS; Laura P. de; KASTRUP, Virgínia. Pista 3 - Cartografar é acompanhar processos. In PASSOS, Eduardo (org) et al. Pistas do método da cartografia: Pesquisa-intervenção e produção de subjetividade. Porto Alegre: Sulina, 2009.

BELLO, Márcia Dal; ICLE, Gilberto. Pode o professor ser um performer? Anais da 36 Reunião Nacional da ANPED, Goiânia, set-out de 2013. Disponível em: 
http://36reuniao.anped.org.br/pdfs trabalhos aprovados/gt24 trabalhos pdfs/gt 242704 texto.pdf

BRASIL. Ministério da Educação. Base Nacional Comum Curricular. Brasília, 2018.

Disponível

em: http://basenacionalcomum.mec.gov.br/images/BNCC El EF 110518 versaofin al site.pdf

CIOTTI, Naira. O mestiço professor performer. In Rebento: Revista de Artes do Espetáculo, São Paulo, n.4, maio de 2013. Disponível em: http://www.periodicos.ia.unesp.br/index.php/rebento/issue/view/13/showToc

COUTINHO, Rejane Galvão et al (Orgs). Se liga na Arte - Manual do professor (Ensino fundamental, anos finais). São Paulo: Editora Moderna, 2018.

FREIRE, Paulo. Pedagogia da Autonomia: Saberes Necessários à Prática Educativa. São Paulo: Paz e Terra, 1996.

HOOKS, Bell. Eros, erotismo e o processo pedagógico. In LOURO, Guacira L. (org). O Corpo Educado - Pedagogias da sexualidade. Belo Horizonte: Autêntica, 2000.

MEIRA, Béa et al (Orgs). Projeto Mosaico: Arte - Manual do professor (Ensino fundamental, anos finais). São Paulo: Scipione, 2015.

MOURA, Eduardo Junio Santos. Des/obediência docente na de/colonialidade da arte/educação na América Latina. In Revista GEARTE, Porto Alegre, v. 6, n. 2, maio/ago, 2019. Disponível em: http://dx.doi.org/10.22456/2357-9854.92905

NARODOWSKI, Mariano. Onze teses urgentes para uma pedagogia do contraisolamento. In Blog do Pensar a Educação, maio de 2020. Disponível em: https://pensaraeducacao.com.br/blogpensaraeducacao/onze-teses-urgentespara-uma-pedagogia-do-contra-isolamento/

OLIVEIRA, Amaurabi. Etnografia e pesquisa educacional: por uma descrição densa da educação. Revista Educação Unisinos, Rio Grande do Sul, vol.17, n.03, set-out de 2013. Disponível em: http://revistas.unisinos.br/index.php/educacao/article/view/edu.2013.173.11/381 8

UTUARI, Solange dos S. et al (Orgs.) Por toda parte - Manual do professor (Ensino fundamental, anos finais). São Paulo: FTD, 2018.

\section{Sobre a autora}

\section{Juliana Maria Girão Carvalho Nascimento}

julianacarvalho@ufc.br

Atriz, diretora e pesquisadora em teatro. Professora adjunta da Licenciatura em Teatro da Universidade Federal do Ceará, possui graduação e mestrado em 
Psicologia (UFC), e doutorado em Artes Cênicas pela UFBA. Iniciou seu percurso no teatro em 1995, no Curso de Arte Dramática (CAD) da UFC.

Recebido em: 14/07/2021

Aprovado em: 10/09/2021 